\title{
跨境流动视阈下的节庆文化与民族认同研究 中越边境苗族花山节案例
}

\author{
唐雪琼 ${ }^{1}$, 钱俊希 ${ }^{2}$, 杨茜好 ${ }^{3}$ \\ (1. 西南林业大学园林学院, 昆明 $650224 ; 2$. 香港大学地理学系, 香港 999077; \\ 3. 华南师范大学地理科学学院, 文化地理与文化产业研究中心,广州 510631)
}

\begin{abstract}
摘 要:边界是分割不同政治实体的界线, 但国家对于边界的管治往往是有弹性的, 因而孕育了丰富的“流动”, 成为 经济融合、社会交流与文化对话的重要场域。跨境民族是受其影响的典型群体,他们在原本生活区域被分隔的情 况下, 从未间断过跨境流动。总体来看, 跨境流动过程中的文化认同及其形成机制是多元复杂的。本文以云南省 河口县中越边境地区的苗族花山节为研究切人点, 通过质性研究方法探讨节庆所折射的民族文化认同与国家认同 的建构过程。研究发现: 跨界的流动性加强了民族文化的交流与认同, 共同促成了花山节的文化传承, 维系了跨境 民族的亲缘关系。这样的跨界流动亦强化了边界所形成的发展轨迹差异的感知, 从而增强了中国籍苗族边民的国 家认同与国家自豪感。
\end{abstract}

关 键 词: 边界; 跨境民族; 节庆; 国家认同; 民族认同

1 引言

国与国之间的边界(border)是人文地理学研究 中的重要概念之一。主流的边界理论通常将其看 作通过一定的法律框架确定, 分割不同的政治实体 的界线。但亦有研究认为边界不是封闭的, 而是经 济融合、社会交流, 以及文化对话的场域(Alvarez Jr, 1995; Ernste et al, 2009; Berndt, 2011)。在经济地 理学领域, 大量的研究已经关注到跨越边界的经济 合作与要素整合 (Grundy-Warr et al, 1999; Shen, 2004; Prokkola, 2011)。然而, 当边界及跨境行为与 文化认同相联系时, 学者更多强调的则是边界的 “封闭性”, 即边界对两侧的社会群体所起到的分割 与隔离的作用(唐雪琼等, 2014)。边界区隔不同群 体的文化身份, 以服务于现代民族一国家(nationstate)的形成。由于民族一国家通常被建构为一个 “想象的共同体”(Anderson, 1983), 并被赋予了一个
统一、均质的文化认同,因此国家边界内的所有公 民均被归纳人一个统一、封闭的认同框架之中。在 这一过程之中, 国家需通过边界的划分和管治, 化 解生活在边界地区的国民的文化身份中内在的“不 纯净” 与 “不稳定” (Paasi, 2002; Van Houtum et al, 2002)。

当然, 国家对于边界的管治是留有余地的。在 国家边界被正式制度化之前, 边界地区往往存在极 为丰富的社会交往与文化融合。基于交流与融合 的历史经验与文化意义,成为现时社会群体的文化 动机与文化资源, 促使跨界流动行为的产生。因 此,边界地区的社会群体往往能通过自下而上的社 会文化实践,与边界的另一侧形成丰富的社会联系 与文化交流(Casey, 2011)。

在这一语境下, 英美学者通常将这类跨界流动 视作对于民族一国家政治秩序的抵抗, 跨界流动的 结果是边民的文化认同更加趋于 “流动”(fluid)和不

收稿日期:2016-12;修订日期:2017-03。

基金项目: 国家自然科学基金项目(41261031, 51668057); 云南省高校重点建设学科风景园林学建设项目[Foundation: National Natural Science Foundation of China, No.41261031, No.51668057; Landscape Architecture as the Key Disciplines at the Provincial Level of Yunnan]。

作者简介:唐雪琼(1969-),女,云南弥勒人,教授,博导, 主要从事社会文化地理、民族文化研究,E-mail: 396464545@qq.com。 
稳定, 致使国家权力施加的国家认同受到削弱 (Anzaldúa, 2007)。跨境民族即为典型的案例。由 于跨越边界而居, 其民族认同难以被国家边界完全 限定。在现有的研究中, 民族认同往往被认为是自 然、有机的, 而国家认同则是人为建构的(Anderson, 1983), 因此自下而上的跨境活动自然是对自上而 下所施加的国家认同的抗拒与削弱。对跨境流动 能否增强跨境民族的国家认同则较少关注。事实 上, 民族认同并非同质与一成不变的, 而是异质及 动态变化的(Hall et al, 1996)。边界的一项重要功 能是将边界两侧分别纳人到不同的政治、经济、社 会与制度框架中, 边界两侧的生存体验必然存在一 定的梯度差异, 因而一个统一均质的民族身份实际 上是很难存在, 或至少是不稳定的。一种可能的情 况是: 跨界流动促使边民对边界两侧进行对比, 而 对差异的感知可能使得边民增强, 而非减弱对边界 特定一侧的认同与归属。

跨境民族在中国的东北、西北以及西南边境地 区均有分布。较典型的包括朝鲜族、苗族、傣族、壮 族、哈萨克族等诸多少数民族。其中, 中国云南省 与越南、老挝、缅甸三国接壤, 国境线长 $4060 \mathrm{~km}$, 国 境线两侧分别居住着壮族、傣族、苗族、瑶族、哈尼 族、景颇族等 16 个跨境民族。跨境民族的地缘分布 形成较早, 而与越南、老挝、缅甸的国界划定则是 20 世纪以来才完成的。因此, 先有民族后有国界, 被 国界分隔的各少数民族有着共同的历史渊源、共同 的习俗文化, 以及共同的族群历史记忆, 民族间的 社会文化交往从未间断。一方面, 跨境民族长期维 持着边界互市、跨境通婚、跨境探亲、跨境参与节日 或仪式等跨境流动实践, 且近年来愈发频繁。边民 通过跨境流动, 不仅维系族群身份, 保存共有的习 俗、记忆及传统, 亦能够通过产品交换与通婚获取 实际的物质利益。从这一意义上来说, 跨境实践对 边民意义重大, 且协商并重构了法定的国家边界所 限定的空间秩序与文化认同(何跃, 2010; 谷家荣, 2013)。另一方面, 如前文所言, 跨境流动过程中的 认同的形成机制是多元的,而非同质与单向的。解 读跨境实践、民族认同、国家认同这 3 个核心概念之 间的复杂关系, 是本文关注的重点。

云南省红河哈尼族彝族自治州河口县桥头乡 老街子、老卡两个村委会与越南老街省孟康县花龙 乡山水相连, 是中越边境苗族集中分布区之一。越 南称苗族为赫蒙族, 其语言和风俗习惯与中国苗族
基本相同, 系跨境而居的同一民族。花山节是中国 一越南边界两侧的苗族共同的最隆重的节日,引发 着频繁的跨境流动, 国界一侧的苗族前往另一侧与 本民族同胞进行庆祝活动, 是中越边界日常生活常 见的文化活动。近年来中越两国的地方政府均介 人花山节活动的组织工作, 边界两侧的花山节的规 模、场地、活动内容也由此产生了巨大的差异, 彰显 出国家的经济发展、现代化水平的差异, 由此影响 到边民的民族认同与国家认同。本文以跨境而居 的苗族花山节活动作为研究的切人点, 以中国云南 省河口县桥头乡老街子和老卡花山节与越南老街 省花龙乡花山节为案例(图 1), 通过实地调查, 分析 跨境的花山节的文化变迁, 探讨节庆所折射的文化 认同与国家认同的建构过程。

总体上,跨境的文化流动虽然维系了跨境的民 族认同与亲缘关系, 但并没有削弱国家认同, 反而 增强了中国籍苗族边民的国家认同与国家自豪 感。究其原因, 主要是由于中国一侧的花山节具有 技术更为先进、演出质量与文化品位更高、内容更 加丰富的特征。中国籍苗族边民通常将上述感知 与中国更为 “现代化”、“发展水平更高”的话语联系 起来, 建构出对于越南籍同胞的社会与文化优越 感,从而增强对“中国人”这一身份的归属感。换言 之, 民族认同的维系与国家认同的增强是并行不 悖, 而非相互对立, 这也是本文对英美文献和理论 进行修正的一个重要依据。

\section{2 跨境流动与身份认同的建构}

对于边境地区的居民来说,边界的存在对他们 的日常生活、社会网络与文化认同均有着极为深刻 的影响。边界的文化意义不是固定、一成不变的 (Balibar, 2002), 不同群体亦通过基于边界的日常活 动获取身份认同,并建构“我者”与“他者”之间的文 化区隔(Newman, 2006)。Anderson(1996)指出, 边界 研究应当关注边界的四重内涵: 即(1)边界是民族一 国家进行地缘政治治理的工具; (2)边界的封闭性不 是绝对的; (3)边界是身份认同的重要载体; (4)边界 是一系列感知与话语的集合。

学术界曾短暂流行过一个“无边界”的大同世 界的论调(Yeung, 1998)。但学者很快发现, 边界依 然是国家的一个重要管治工具, 并以此界定地缘政 治秩序, 明确“我者”与“他者”的身份差异(Scuzza- 


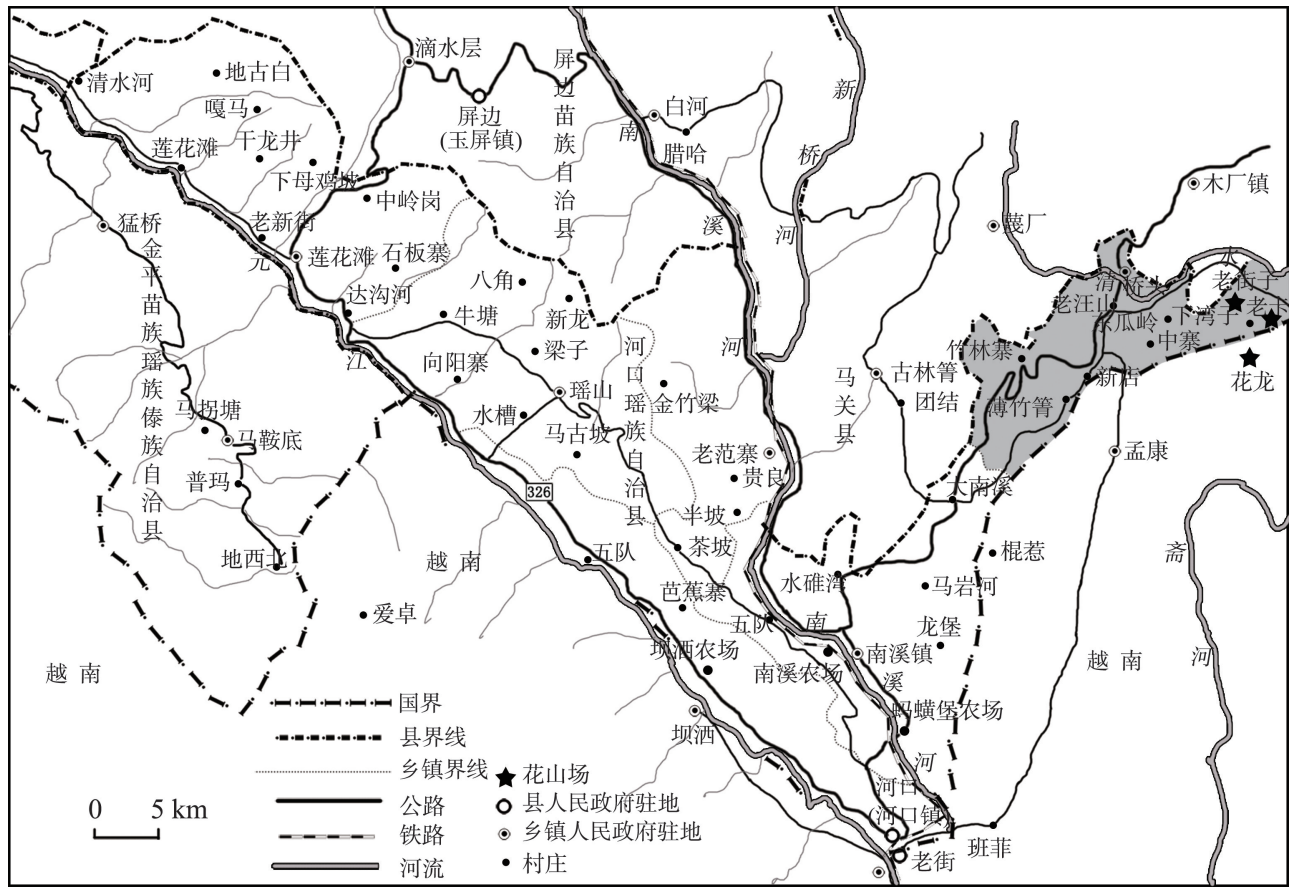

图 1 案例地区位图

Fig.1 Location of the case study site

rello et al, 2013)。不过,边境地区的交流、融合、杂 交亦永恒存在(Ravisco, 2010)。有关跨境流动与身 份认同的关系, 学界目前有两种主要的观点: 第一 种观点认为跨境流动是对自上而下设定的民族一 国家秩序的抗拒。国家划定的正式边界确实在很 多情况下将完整的文化社区强行划分到不同的政 治实体。因此, 跨境流动常常是对国家权力的一种 调适与响应 (Fondahl et al, 2003)。Dell'Agnese (2015)有关美国一墨西哥边界地区流行音乐的研究 指出, 边界群体的音乐创造通常表达出对于边界合 理性的质疑, 以及对于国家边界管治的不满。另有 研究则更为激进地指出, 封闭、同质的民族一国家 秩序体现了现代欧洲的意识形态, 而在其他区域情 境下并非是顺理成章的。原住民对边界的理解,往 往更加强调开放、流动与交流，而非封闭与区隔 (Lloyd et al, 2010)。Jones(2012)对印度一孟加拉国 边界频繁的无证越境行为进行了研究, 指出边民一 方面尊重边界线的存在, 同时通过跨境流动来满足 日常的生活诉求, 这种跨境流动并不会对国家与边 民之间不对等的权力关系造成重大影响,但仍然可 以看作是对边界的“叛逆”(defiance)或 “越轨”(transgression) (Lamb, 2014)。

与之相反, 少数文献倾向于第二种观点, 认为
跨境行为与认同之间的关系是复杂和多元的。 Newman(2006)提出,边界所划定的国家身份、国族 认同具有强大的意识形态的力量,亦深刻地影响了 群体有关“自我”的定义。尤其是当边界两侧的社 会经济环境差异巨大时,跨界的交流可能强化边界 所划定的身份与归属。Lamb(2014)有关泰国一缅 甸边界的研究便指出,边民对边界的理解与中央政 府未必有显著区别,边民亦可能基于边界将另一侧 的群体塑造为 “他者”。而 Doevenspeck(2011)有关 刚果民主共和国一卢旺达边界的研究则表明,频繁 的跨境流动确实可能增强认同的弹性,但并不能完 全消解国家边界所界定的 “我者”与 “他者” 的差 异。Lamb 与 Doevenspeck 虽没有以跨境民族作为 直接研究对象, 但提供了一个理论线索, 即边境地 区的居民对于边界的认知可能是多样甚至矛盾的。

有关中国边境的跨境民族研究, 也已关注到身 份认同是跨境空间实践研究中的一个重要话题。 与边境研究的整体情况类似,这些研究中的大部分 认为边界对跨境民族的日常生活平添了制度阻隔, 但边民可通过一系列的对策或策略来超越边界的 限制(Turner, 2013)。在这一过程之中, 民族认同强 于民族一国家秩序所界定的国家认同。例如,有关 中国云南西双版纳的傣泑人(傣族的一支)的跨境流 
动的研究指出, 傣测人倾向于将自我塑造为 “弹性 的主体” (flexible subjects), 在与老挝的傣族人进行 跨境互动的过程中, 他们高度强调两侧共享的“傣 族” 身份，而弱化其 “中国公民” 的身份 (Diana, 2013)。同民族的相互理解和信任等非经济要素条 件, 为跨境经济活动的顺利开展打下了坚实的基础 (马羽炜等, 2011)。

Sturgen(2013)的研究则揭示了一个更为复杂的 图景。一方面, 中国一老挝边界中国一侧的哈尼族 与傣族利用边界两侧共有的民族身份跨境前往老 挝进行香蕉种植; 另一方面, 他们高度强调(而非弱 化)自身的“中国人”身份。其原因是中国更发达的 经济使得 “中国人”的身份被赋予了文明、现代与高 素质的意涵, 为中国籍边民在跨境经济活动中的主 导地位提供了文化上的合法性依据。

总之, 由于边界两侧客观存在的社会、经济与 制度差异, 边民在认同与身份的选择上具有相当的 自主性和弹性, 跨境民族的文化认同是动态和不稳 定的。民族认同和国家认同通过社会一空间的实 践被不断的重构和再生产(Bhabha, 1994)。跨境民 族一方面适应和协商既有的地缘政治秩序和国家 权力, 另一方面又在不断接触、交流与碰撞中, 实现 日常生活的诉求, 重新理解和重新定义自身的文化 认同。

\section{3 案例背景与研究方法}

花山节以庆典为载体, 推动苗族文化的传承、 传播与发展, 千百年来被广大苗族同胞所认可, 成 为苗族的标志性文化, 也是苗族文化认同的一个重 要符号。节日的具体时间各地不一, 云南南部的苗 族在每年农历正月初三至初八间庆祝花山节。花 山节活动分为立杆、祭杆、闹杆、倒杆 4 个阶段, 最隆 重的是祭杆和闹杆。每年腊月十六立花杆, 次年正 月初三或初四早晨祭花杆仪式标志花山节开始, 闹 杆的内容传统上以爬花杆、跳芦笙舞、对歌为主。 近年来, 花山节增加了开幕式、文艺表演、拔河比 赛、斗鸡、斗鸟、打陀螺、乃至选美比赛、商贸活动等 内容, 3 天后逢双日倒杆即标志着花山节闭幕。

研究案例地河口瑶族自治县桥头苗族壮族自 治乡的东南部与越南老街省孟康县接壤, 国境线长 $81 \mathrm{~km}$ 。这里的苗族自古有过花山节的传统, 由民 间自发组织, 规模不大。随着 “富民兴边” “固边睦
邻”、“文化强国”等国家项目的推动,政府致力于展 示桥头乡的现代化进程和丰富的传统民族民间文 化,推动旅游业和区域经济发展。2005 年以后, 乡 政府介人花山节组织活动, 民办官助, 政府确定花 山节活动以突出 “团结、开放、展示苗族传统文化” 为主题, 制定花山节活动方案, 筹集活动经费, 由老 卡、老街子村委会轮流承办花山节活动,每个村委 会承办 3 年,随后再轮换。

越南赫蒙族的主体在距今 100 140年间由云南 迁往越南, 现今人口 100 余万人(石茂明, 2004), 主 要分布于越南北部, 在与中国接壤的边境地区分布 较广, 且传承着花山节的习俗。过去, 踩花山一般 为村寨间轮流举办, 每 3 年换一个地方, 花山场分散 于苗族村落间。2000年以后, 与桥头乡接壤的越南 老街省孟康县政府将花山场固定在花龙乡, 由此花龙 乡花山节成为越南北部影响最大的节庆活动之一。

研究者分别于 2013年10月 26-11月9日、2014 年 2月 2-6 日 (当年春节的大年初二至初六)、2015 年 10月 9-15日 3 次到河口县桥头乡老卡和老街子 村委会、中国老街子花山节和越南花龙乡花山节现 场进行田野调查, 调查时间合计 27 天, 调查方法为 参与式观察和深度访谈。研究者对中国和越南花 山节的仪式、程序、内容与物质表达进行了参与式 观察和详细记录。访谈对象共 39 人, 其中中国苗族 32 人, 越南苗族 7 人。在受访者的职业构成方面, 双方乡政府和村委会参与花山节的干部 12 人、中国 苗族学者 3 人、双方苗族群众 24 人。在性别方面, 男性 23 人,女性 16 人。由于老卡口岸非边民不能 出人境, 到越南花龙调研较为不便, 因此本文主要 访谈对象为中国人, 重点调查中国的苗族边民在跨 境的花山节流动中产生的差异性体验, 以及花山节 如何既能维系苗族的民族认同，又同时强化“中国 人”的国家认同。

\section{4 花山节引发的跨境流动}

\section{1 花山节跨境流动的历史脉络}

中越边民花山节往来交流有历史渊源。19世 纪末之前, 以中国为核心的中央帝国的朝贡体系塑 造了东亚与东南亚的地缘政治秩序。这一地缘秩 序与现代社会的民族一国家秩序截然不同, 清王朝 为越南的宗主国，两国之间边界划分因此不甚明 确, 边民的生存体验受到边界的影响不深。中法战 
争后, 中国将越南宗主国地位转移给法国。1887 年, 清王朝和法国殖民当局签订双边条约, 勘定了 中越陆地边界线(引自齐鹏飞, 2013),法定的国家边 界逐步形成, 边界两侧的边民也逐渐有了模糊的国 民意识。由于山水相连的自然环境、同宗同源的民 族情感,加上 20 世纪 50、60年代中越“同志加兄弟” 的密切关系, 边界管制并不严格, 中越边民跨境流 动十分频繁。花山节作为维系民族感情的重要节 日, 引发的跨境流动具有规模大、时间集中的特点, 使得花山节成为了 “展演” (perform)民族认同的重 要场域。边民们穿行于边境上的便道, 歇住在亲朋 家里, 在花山场自娱自乐、国家边界所界定的地缘 政治秩序被临时地逾越和淡化。

“那时, 越南过来踩花山的人比现在多很多, 都 穿的苗族衣服, 从穿着看不出来是哪个国家的人, 不过亲戚多、朋友多, 知道他们是越南人。” (熊某 某,男,60岁,中国人,访谈时间: 2013.10.30)

“我们(中国)的花山节比他们(越南)早一天, 那 时候嘛, 初三就叫亲戚过来要(玩), 初四去那边要 (玩)””。(罗某某, 女, 71 岁, 中国人, 访谈时间: 2013.11.5)

20 世纪 70 年代末, 中越爆发边境战争。这前 后的十几年间, 中越双边关系恶化, 民族一国家之 间的地缘政治冲突最直接的体现在边界管制的增 强。加上边民负有支持前线部队的义务, 边界另一 侧的同族人被赋予了强烈的 “外敌” 意涵, 因此民族 认同不可避免地受到了边界所划定的地缘秩序与 文化秩序的冲击。边民不得不停止正常的边贸往 来和文化互动, 花山节的跨界庆祝也一并停滞。

\subsection{1 世纪的花山节跨境流动}

随着中越关系正常化, 边境地区跨境的日常活 动与民间文化交流的传统迅速恢复。2000年以后， 越南花龙乡和中国桥头乡政府分别介人花山节活 动, 活动内容更加丰富, 规模日益扩大, 又由于道路 条件和交通工具的改善, 花山节引发的跨境流动愈 发增强。这一现象在访谈之中也得到了证实:

“去越南玩的人多呢, 去前年来老卡踩花山, 地 方太小呆不下, 好多人都去越南了, 几百人上千人, 还多”。(熊某某, 男, 40 岁, 中国人, 访谈时间: 2014.2.3)

花山节跨境流动的规模没有准确的统计数据, 边民们根据居住的村寨与花山场的位置, 选择从老
卡口岸或边境便道出人。当地人估计每年中国边 民参加越南花山节的有几百人, 从越南前来桥头乡 参加庆祝活动的可能有二、三百人至五、六百人。

2013 年开始,花山节互访上升到政府层面,桥 头乡政府和花龙乡政府互相邀请, 由政府领导、工 作人员、文艺表演队组成代表团, 分别于花山节第 一天互访交流。以研究者深人观察的 2014 年花山 节为例, 大年初三中国花山节第一天上午 8 时 30 分, 桥头乡党政领导在老卡边防检查站迎接越南花 山节代表团, 到花山场参加花山节开幕式、观看民 族歌舞表演和各项民间活动, 目的是重温有关民族 文化与传统的集体记忆。下午, 中方送客至老卡边 防检查站。大年初四越南花山节第一天, 越南花龙 乡领导到老卡边防检查站迎接中国花山节代表团, 活动时间和具体安排一致。

\section{5 中越花山节的传承、变迁与体验}

中越两国的花山节浓缩了一个群体共有的传 统,隐含着集体的记忆, 在时间、场地、祭祀仪式、活 动内容等方面共有一整套的仪式和规范, 在苗族文 化的传承、发展与认同中发挥着重要作用。然而, 21 世纪以来, 中国社会经济的迅猛发展, 文化全球 化、现代性的影响从经济发达地区延及边境区域, 渗透至花山节活动的各个环节。中国桥头乡老卡、 老街子花山节和越南花龙花山节在仪式、场地、活 动内容等方面都显现出较多的不同,边界两侧的苗 族群众在频繁的跨界流动中感受到了民族一国家 的边界在塑造差异方面的作用。

\section{1 承继“原真性”的越南花山节}

花山蕴含山丘或平缓的山坡之意, 限定着花山 场地的选择。越南花龙的花山场地,位于距乡政府 驻地 $1 \mathrm{~km}$ 外的起伏平缓的山丘群, 平整出 100 多 $\mathrm{km}^{2}$ 的地块作为祭祀和表演场地, 主花杆插于表演 场正中,主花杆后 $60 \mathrm{~m}$ 处插有稍细的副花杆,两侧 设置塑料座椅 20 余个, 四周的山包为天然看台。山 丘间的低缓处搭建了近百处临时帐篷, 为商贸区, 经营烧烤、煮食、零食、小百货等。场地随山就势, 自然有序。

农历腊月十六或二十六立花杆,正月初四祭 杆,正月初六倒杆, 上香、敬酒、念祈词、杀鸡等活动 传承着神圣的宗教意义。祭杆仪式后,身背小孩的 
苗族群众自发参加的绕杆活动, 表达着苗族村民对 花杆的崇敬、对神灵的感激, 回应花山节来源中的 “求子”之说。

闹杆是花山节的重要活动, 连续 3 天, 包括开幕 式、歌舞表演、对歌、倒爬花杆、斗鸡、斗鸟、打磨秋、 三节棍、跳钱、练棍等项目, 歌舞活动分为开幕式专 场表演和民众自发表演。

对歌是花山节传承时间最长、参与人数最多的 活动项目, 对歌人及听歌者形成多处聚集人群, 参 与者年龄从 20 多岁至 50 多岁。对歌以情感交流为 主, 同时担负传统的男女恋爱和社会交往的功能。 虽有固定的传统曲调, 但没有固定的歌词, 词随情 生, 表达对歌人平时的生产生活感悟和民族文化的 知识积累。花山节也是苗族芦笙手们展示传统技 艺的舞台。演出分为单人表演或双人表演, 呈现民 族熟悉的文化意义与符号。

越南花龙的花山节原真地继承了上述的传统 节庆内容。开幕式及专场表演是越南一侧的花山 节仅有的新创活动, 但仅仅借鉴了现代庆典文化的 组织方式, 其间展示的仍是越南苗族原生态的歌 舞, 以苗歌独唱、芦笙舞为主, 符合现代都市文化品 位的表演十分稀缺。相反, 中国代表团表演的 3 个 舞蹈节目起到了渲染当代流行文化气氛的作用。 总体而言,花龙的花山节强调传统以及 “原真性”, 通过历经久远的祭祀仪式、对歌、芦笙舞表达着当 地苗族人民的集体记忆, 表达娱神祈福、代际绵延 的愿望, 核心目的是达到一种群体欢愉的状态(郑 宇等, 2013)。

\section{2 现代性影响下的中国老街子花山节}

老街子花山节的立花杆、祭杆、倒杆仪式沿袭 传统的上香、敬酒、念祈词、杀鸡祭祀等活动, 传承 了花山文化的仪式过程和宗教内涵。然而, 其外在 形式和物质表达都深受都市流行文化和现代性的 影响。

首先, 花山场地的选择和布置强调舞台化效果 和实用功能, 而花山文化中约定俗成的要求则并非 首要考量的因素。以四面环山的山间平地为花山 场, 场地功能分区十分明确, 设置表演区、观赏区、 商贸区。表演区用混泥土浇灌 $0.8 \mathrm{~m}$ 高、 $120 \mathrm{~m}^{2}$ 的 舞台, 配备先进的音响设备, 悬挂底幕、横幅, 上铺 红色地毯。舞台后边缘立花杆 2 棵, 斜拉的彩旗增 加了节日的氛围, 观赏区和商贸区满足观众的饮食 和游乐需求。
其次,花山节的主办者热衷于现代化、舞台化 的展演。原本神秘的祭杆和绕杆仪式以舞台化的 真实性展示给本民族和外来游客。苗族头人口念 祈词、杀鸡、燃点香纸, 在有节奏的阵阵鼓声和元䒕 的牛角声中祭祀天地和花杆, 事毕后双手端着祭 物, 带领 2 名护卫, 9 男 8 女及桥头乡板登队、棍棒武 术队、大刀队、芦笙队和苗学会的花伞队进行绕花 杆仪式。开幕式歌舞表演成为闹杆活动的重要内 容。表演内容形式多样, 既有苗族现代舞蹈《走苗 山》、苗歌汉语独唱, 也有现代小品《人与猪》、快板 《兴地睦边固边疆》、舞蹈《tik-tok》、《啦啦操》等, 将 现代都市流行文化融入传统文化。歌舞表演的风 格虽然很多以苗族传统为内核, 但同时强调对都市 文化风格与文化倾向的借鉴, 以彰显本地苗族对于 现代性的诉求与认同。同时,表演的服装是为了舞 台化展演特制, 不仅设计更为考究, 也融人了明显 的都市时尚的元素。

值得注意的是, 在桥头乡, 传统花山节最重要 的对歌、跳芦笙由核心转为边缘。究其原因, 主要 是随着都市流行文化的进人, 本地年轻人对于苗族 传统的兴趣逐渐减弱, 有关传统文化的地方性传承 有式微的趋势。年轻一代热衷于都市的流行音乐 与舞台表演形式, 对于对歌中沿用的苗族歌曲不甚 熟悉,传统芦笙舞的舞步也逐渐失传。尽管本地政 府每天发放 50 元对歌奖励, 但也仅有三、四对中年 男女在舞台后边缘对唱, 跳芦笙舞的本地人也较少 见。总体而言, 尽管中越边界两侧的苗族社群重视 民族认同的维系,边界的区隔作用对具体的社会文 化实践和体验起到的分化作用亦显而易见。

\section{3 总结: 发展轨迹的差异与花山节的演变}

跨越边界的相邻地域同一民族的花山节活动, 延续着花山节固有的立杆、祭杆、闹杆、倒杆的习 俗, 为官方和本地文化精英所推崇的跨越边界的、 统一的“苗族文化”。但由于边界的存在, 看似均 质、统一的民族文化实际上已经逐渐从内部开始分 化。越南花龙花山节的场地选择, 以山间平地为表 演场, 自然坡地为看台。沿袭传统的祭祀仪式, 服 装与道具都直接取自现实生活, 历史传承的对歌、 芦笙舞仍然是花山节的主导活动。但中国一侧的 文化活动却并非拘泥于一个固定不变的“传统”。 花山场地选择更看重功能性, 祭杆仪式舞台化, 强 调展演过程,而弱化原有的宗教内涵。尤其是开幕 式文艺表演,显著受到春节联欢晚会等都市流行文 
化的影响,成为中国一侧边民的文化现代性展演。

因此,花山节并非仅是维系共享的文化认同与 集体记忆的场域。对于边界两侧的苗族人来说, 前 往边界另一侧就是一个体验“差异”的过程。尤其 是在中国经济高速发展, 而越南经济发展相对滞后 的宏观背景之下, 由民族一国家的中心向边缘扩散 的发展与现代化过程使得边界两侧的区域虽然唇 齿相依, 却呈现出截然不同的生存体验。在受访的 苗族人的话语中, 中国一侧更多地被赋予 “发展” “进步”与 “现代” 的文化标签, 而越南一侧则更多被 描述为相对 “传统”与 “落后”。这一感知也不可避 免被投射到对于花山节的话语建构中:

“我们是跟着新时代走的, 舞蹈这些都是新创 意的, 地上(花山节舞台)都铺了红地毯, 栓了小旗 子, 布置得漂亮。那些表演都是排练过的, 人多、整 齐、热闹得很。” “越南的(花山节)比较传统一点, 老 年人比较喜欢一点”(集体访谈, 中国人,访谈时间: 2015.10.11)

在这一情景之下, 通过跨界流动参加两侧不同 的花山节, 边界两侧的苗族村民能在数天之内分别 经历具有原真性和现代性特征的花山节, 获得花山 文化变迁的第一手感性体验。差异性的体验, 不断 修正苗族边民自身对于花山文化的认知, 从文化内 涵和物质形式 2 个层面建构新的文化意义。总的来 说, 新的文化意义的核心是将中国一侧的苗族与发 展、现代化和都市文化联系起来, 从而建构起对越 南一侧苗族的“优越感”, 重新确认中国一越南之间 的文化差异。这其中, 文化内涵维度包括对于现代 都市文化风格和品位的认同和追求, 以及与传统乡 村文化的对比; 而物质形式维度则是中国一侧设备 先进、高度舞台化的空间组织形式与越南一侧技术 落后、依托自然地形的空间组织形式的鲜明对比。

\section{6 花山节与苗族边民的文化认同建构}

与此同时, 苗族边民通过比较花山节差异, 反 思传统与发展之间的复杂关系, 并重新定义自身的 文化认同, 以及实现不同的文化倾向之间的对话。

\section{1 花山节过程中传统与现代的互动与协商}

祭祀是花山文化的灵魂, 花山节立杆、祭杆、闹 杆、倒杆约定俗成的 4 个阶段中有 3 个阶段有祭祀 的内容, 承载着苗族民众的精神世界, 中越两边对 其都有着强烈的认同:
“我们的立花杆、祭花杆、倒花杆的传统(仪式) 跟越南都是一样的,都要烧纸、敬酒、杀鸡、磕头; 要 说改变呢, 就是绕杆活动, 我们变成表演了, 但是祭 杆(绕杆前)我们还是一样在台子上杀鸡祭的。立花 杆、祭花杆、倒花杆还是必须要保持原来的传统。” (集体访谈,中国人,2015.10.11)

在越南花龙, 政府考虑庞大人群的用地需求和 舞台表演的要求, 前几年在农贸市场那里举办, 场 地比较宽敞。但是苗族老人们认为花山节要在山 上过, 不能在平地或是洼地, 于是将花山场移到离 乡政府 $1 \mathrm{~km}$ 以外的群山中的一个小山包上。花山 场中关键要素花杆的位置也强调传统的习俗规范:

“花杆栽后点行吗? 栽后点场地宽, 节目好表 演, 老人说不行, 花杆一定要栽在场地的中央, 就只 能栽在中间了”。(王某某, 男, 50 岁, 越南人, 访谈 时间:2014.2.3)

花龙花山节的花山场地和花杆位置的功能性 建议都未得到苗族长者们的应允, 村民们遵循着族 中长者的文化认同, 强调花山场、花杆等花山文化 符号要严格依循规矩, 传承传统、原真的花山节 文化。

相反, 中国桥头乡的花山场的选择, 更多考虑 平整、容量、方便观看等要素,拓展了花山的理解。 在访谈中, 老街子的苗族村民以“山野”这一理念拓 展了花山场地选择的局限, 考虑舞台的效果调整了 花杆的位置, 包容着场地选择中的功能考虑:

“我们的花山场周围也是山, 是绿色的,代表我 们不是在城里面或者寨子里面搞, 花山是在野外踩 的, 只要是山野就可以了”(杨某某, 男, 30多岁, 中 国人,访谈时间: 2015.10.12)

有趣的是, 中国花山场地和花杆布置也得到了 越南主办者的赞许, 促使他们思考如何平衡传统与 新的空间需求:

“你们的花山节有进步, 有改革, 但传统还在。 老街子花山节的花杆就后移了, 前面的场地很大, 这是传统文化的改革, 我们要学习, 明年我要坚持 把花杆后移, 保持民族传统也要与时俱进。” (王某 某,男,50岁,越南人,访谈时间:2014.2.3)

同时,舞台化表演是桥头乡花山节的一种创 新。在本地苗族村民的眼中, 传统民族文化与都市 流行文化是并行不悖, 互相融合的。桥头乡花山节 的组织者和表演者都强调, 创新事实上源于传统, 是苗族文化的现代演绎: 
“我们表演的苗族节目都源于苗族文化, 比如 踢段子舞, 就是表现我们苗族的踢段子活动的。苗 族服装走秀, 展示过去到现在、不同年代的苗族传 统服饰文化。甘蔗舞展示我们桥头苗族壮族乡过 去这一年甘蔗生产的丰收景象。所以呢, 虽然开幕 式是学习现代节庆活动的仪式, 但是内容还是我们 的苗族文化。” (熊某某, 女, 30 岁, 中国人, 访谈时 间:2015.10.9)

同样, 现代的歌舞表演也得到了越南苗族人的 喜爱。有的越南籍苗族边民早晨 4 点就从家里出 发, 赶到花山场观看中国代表团的歌舞表演, 表明 普罗大众对现代流行文化的渴望、追求与认可。总 体而言,桥头乡花山节在体现旧的集体记忆的同 时, 更为强调制造新的集体记忆, 将民族传统文化 符号与现代元素有机融合。这种传统文化与现代 元素的结合, 体现的不仅是传统文化在愈加开放的 社会环境寻求创新、发展的期盼, 也包含本地政府 对政治与经济展示的诉求, 即借重新包装的民族文 化呈现实力雄厚、蓬勃发展的国家形象, 以及边疆 少数民族新的 “时代精神” (zeitgeist): 即积极融人自 身所属的民族一国家的发展趋势, 以改变自身在国 家政治经济版图中的“边缘”地位。

\section{2 民族认同与国家认同的建构机制}

跨界流动性一方面维系了共有的民族认同与 集体记忆, 另一方面也促使边境两侧的苗族人认识 边界两侧客观存在的社会、经济与文化差异, 同时 思考自身的国家归属。最典型的体现是: 中国籍的 苗族人对于中国高速发展与现代化影响下的花山 节给予了积极的评价, 特别是中青年一代的苗族人 明显更倾向于中国的花山节, 认为舞台宏大、技术 设备先进、节目内容丰富、符合都市流行文化的文 化品位。在中年与青年一辈的苗族人眼中, 现代元 素的融人, 并未造成花山节文化价值的降低, 反而 使得花山节更好玩、更热闹：

“我们在外面打工接触的都是比较现代的东 西, 喜欢我们的花山节的那些音乐, 舞跳呢好, 衣服 穿得好看。”(杨某某, 男, 20 多岁, 中国苗族村民, 访 谈时间: 2015.10.14)

对于花山节的现代化转型的认同, 也投射到中 国籍苗族人的国家认同上。在访谈的过程中, 桥头 乡的苗族人普遍认为边界的存在对于中国一侧的 苗族具有积极意义, 使其能以中国公民的身份积极 地融人到改革时代中国的发展与现代化转型之
中。桥头乡花山节更为宏大的舞台氛围、更为先进 的技术设备以及时尚的表演,也成为中国籍苗族人 用以展演其“现代”社会公民身份的社会一文化空 间。在此背景之下, 桥头乡的苗族人普遍表达出强 烈的国家归属以及对“中国人”身份的自豪感。相 应地, 尽管越南在 1986 年越共六大之后也实施了 “革新开放”的政策,但该政策对作为边疆地区的花 龙乡扩散与影响还较微弱。因此, 中国籍苗族人倾 向于将越南与 “发展滞后”、“文化落后”等负面意涵 联系在一起, 并进一步强化了“中国人”的身份所承 载的自豪感与身份认同。换而言之,跨境民族的跨 界流动不仅没有削弱国家认同, 而且反而固化了对 民族一国家的归属感：

“那边的(越南)花山节活动不发奖金, 只发点 伞、毛巾啊,这些纪念品,不值几块钱。舞台、音响 那些都是学着我们整的, 文艺节目太单调了。(熊 某某,男,40多岁,中国人,访谈时间: 2015.10.13)

“花山节政府投入估计有 10 多万呢, 我们国家 实力强了, 重视民族文化遗产保护。”(集体访谈, 中 国人,访谈时间:2015.10.11)

不可否认的是, 中国花山节的现代变迁使得一 些苗族文化学者和文化精英思考自身的文化归宿, 产生文化焦虑感和自觉性。他们似乎更认同越南 的花山节, 认为越南的节庆方式更加热闹、纯朴、真 实、传统一“那才是我们苗族真正的花山节, 我喜 欢那种氛围, 原生态, 传统, 是我们民族的文化。 (罗某某, 男,40岁,中国人,访谈时间: 2015.10.09)。 然而, 文化精英的怀旧情结在花山节这一文化场域 中并非主流。一方面, 国家希望展演的是一个不断 趋向于进步与发展的现代化过程。在地方政府强 有力的支持与推动下, “办得更多姿多彩一点, 看起 来层次更高一点” (集体访谈, 中国人, 访谈时间: 2015.10.11)已成为了地方官员和民众的共识。花山 节展示生产丰收、社会进步、经济发展的边境村寨 的新面貌, 强化社会成员的发展意识, 使其在精神 上、意识上对当下国家和社会的主流价值观产生共 鸣。另一方面，“现代人”的文化身份也是中国一侧 的苗族人所积极践行的。桥头乡经过严格的编舞 和排练的 “高质量”文化展演被当地人认为是现代 “文明”与“素养”的重要体现; 经过仔细设计、制作 的演出服装也更符合“时尚”的标准和“城市文化品 位”。总而言之, 花山节经历了一个有意识的、动态 的再生产过程, 不断从一个小规模的民间节日成长 
为新型的、场面宏大、宗教与世俗意义交融的现代 节庆, 成为边境区域展示国家实力、激发爱国情感 的重要场域。

\section{7 结论}

中越两国由于发展水平的差异, 现代性在花山 节活动中的介人深浅不一, 边界两侧的花山节文化 变迁与建构呈现不同的特点。跨境的流动让村民 们能与国界另一侧的花山节进行直观地比较, 加强 了苗族村民对于差异性的体验。边界两侧花山节 的差异性并未导致文化区隔的产生,民族认同的维 系与国家认同的强化是并行不悖的。一方面, 融人 现代元素的花山节与相对更为 “原真” 的花山节一 样得到苗族人的喜爱, 跨边界的文化认同得到维系 和强化, 边界所界定的地缘政治秩序在一定程度上 被淡化。另一方面, 中国一侧的苗族身份被刻写上 “现代”的标签。中国的苗族人, 尤其是年轻一代, 倾向于将对中国的国家归属解读为一种文化的优 越性, 来解释、表达中国苗族与越南苗族的差异; 相 应地, 越南的苗族则被贴上了传统、原真、落后的 标签。

跨界的流动性加强了民族文化的交流与认同， 共同促成了花山节的文化传承。通过跨越边界参 加另一侧的节庆活动, 中越边界的苗族社群不断地 协商着民族一国家所界定的地缘政治秩序与公民 归属, 在不挑战民族一国家主权的前提下, 以仪式 化的空间实践为媒介,维持了共有的集体记忆与文 化传统的生命力。然而, 这并不妨碍花山节成为一 个展演国家实力与不同的社会经济发展轨迹的空 间: 在中国一侧传达强盛、领先的国家形象, 而在越 南一侧则生产了“原真”、“落后”的文化意涵。边界 两侧花山节的巨大差异, 最终使边境地区的苗族边 民认识到国家力量对于地方发展的重要性, 激发中 国边民的自豪情绪和归属感, 强化了对于国家的认 同。总之, 本文与国外文献中有关跨境流动与身份 认同关系的理论进行了对比, 并对其跨境流动强化 跨境民族认同而弱化国家认同的相关结论提出了 质疑。本文一方面呼应了一个受学界关注较少的 观点, 即跨境流动与国家认同之间的关系是变化、 不确定和不稳定的; 另一方面又通过实证研究对上 述观点进行了充实和理论上的提升, 为跨境民族的
身份认同研究贡献了中国知识。

\section{参考文献(References)}

谷家荣. 2013. 边民生活政治: 滇越跨境民族的记忆、心境与 行动 [M]. 北京: 社会科学文献出版社. [Gu J R. 2013. Border people's life politics: Memories, mentality and actions among minority ethnic populations along the ChinaVietnam border in Yunnan Province[M]. Beijing, China: Social Sciences Academic Press.]

何跃. 2010. 边民主义与跨界民族主义: 以中国西南边疆为 研究对象 [J]. 云南民族大学学报: 哲学社会科学版, 27 (1): 24-29. [He Y. 2010. Border-inhabitantism and crossborder ethnicalism: A case study of Southwest China[J]. Journal of Yunnan Nationalities University: Social Sciences, 27(1): 24-29.]

马羽炜, 张雨龙. 2011. 跨境橡胶种植对民族认同和国家认 同的影响: 以中老边境两个哈尼族(阿卡人)村寨为例 [J]. 思想战线, 37(3): 17-21. [Ma C W, Zhang Y L. 2011. The influence of the cross- border rubber plantation on ethnic identity and national identity: A case study of two Hani/ Aka Villages in the Sino-Laos Borderland[J]. Thinking, 37 (3): 17-21.]

齐鹏飞. 2013. 中越陆地边界谈判的历史及其基本经验再认 识 [J]. 当代中国史研究, 20(3): 60-68. [Qi P F. 2013. The realization of the history and its basic experience of the $\mathrm{Si}$ no-Vietnamese land border negotiations[J]. Contemporary China History Studies, 20(3): 60-68.]

石茂明. 2004. 跨国苗族研究: 民族与国家的边界 [M]. 北京: 民族出版社: 165-166. [Shi M M. 2004. A transnational study of the Miao: National borderlines and ethnics boundaries[M]. Beijing, China: The Ethnic Publishing House: 165-166.]

唐雪琼, 杨茜好, 钱俊希. 2014. 社会建构主义视角下的边 界: 研究综述与启示 [J]. 地理科学进展, 33(7): 969-978. [Tang X Q, Yang X H, Qian J X. 2014. Conceptualizing border from a social constructionist perspective: Current progress and implications for future research[J]. Progress in Geography, 33(7): 969-978.]

郑宇, 曾静. 2013. 仪式类型与社会边界: 越南老街省孟康县 坡龙乡坡龙街赫蒙族调查研究 [M]. 北京: 中国社会科学 出版社: 220. [Zheng Y, Zeng J. 2013. Ritual types and social boundaries: A case study of the Hmong of Pha Long village, Lao Cai province, Vietnam[M]. Beijing, China: China Social Sciences Press: 220.]

Alvarez R R Jr. 1995. The Mexican-US border: The making of an anthropology of borderlands[J]. Annual Review of An- 
thropology, 24(1): 447-470.

Anderson B. 1983. Imagined communities: Reflections on the origin and spread of nationalism[M]. London, UK: Verso.

Anderson M. 1996. Frontiers: Territory and state formation in the modern world[M]. Cambridge, UK: Polity Press.

Anzaldúa G. 2007. Borderlands/La Frontera: The new mestiza [M]. 3rd ed. San Francisco,CA: Aunt Lute Books.

Balibar E. 2002. Politics and the other scene[M]. London, UK: Verso.

Berndt C, Boeckler M. 2011. Performative regional (dis)integration: Transnational markets, mobile commodities, and bordered North- South differences[J]. Environment and Planning A, 43(5): 1057-1078.

Bhabha H K. 1994. The location of culture[M]. London, UK: Routledge.

Casey E S. 2011. Border versus boundary at La Frontera[J]. Environment and Planning D: Society and Space, 29(3): 384-398

Dell'Agnese E. 2015. "Welcome to Tijuana": Popular music on the US-Mexico border[J]. Geopolitics, 20(1): 171-192.

Diana A. 2013. The experimental governing of mobility and trade on the China-Laos frontier: The Tai Lue case[J]. Singapore Journal of Tropical Geography, 34(1): 25-39.

Doevenspeck M. 2011. Constructing the border from below: Narratives from the Congolese- Rwandan state boundary [J]. Political Geography, 30(3): 129-142.

Ernste H, Van Houtum H, Zoomers A. 2009. Trans-world: Debating the place and borders of places in the age of transnationalism[J]. Tijdschrift voor Economische en Sociale Geografie, 100(5): 577-586.

Fondahl G, Sirina A. 2003. Working borders and shifting identities in the Russian Far North[J]. Geoforum, 34(4): 541556.

Grundy-Warr C, Peachey K, Perry M. 1999. Fragmented integration in the Singapore- Indonesian border zone: Southeast Asia's 'growth triangle' against the global economy[J]. International Journal of Urban and Regional Research, 23 (2): 304-328.

Hall S, Du Gay P. 1996. Questions of cultural identity[M]. London, UK: SAGE.

Jones R. 2012. Spaces of refusal: Rethinking sovereign power and resistance at the border[J]. Annals of the Association of American Geographers, 102(3): 685-699.

Lamb V. 2014. "Where is the border?" Villagers, environmental consultants and the 'work' of the Thai-Burma border[J]. Political Geography, 40: 1-12.

Lloyd K, Suchet-Pearson S, Wright S, et al. 2010. Stories of crossings and connections from Bawaka, North East Arnhem Land, Australia[J]. Social \& Cultural Geography, 11 (7): 701-717.

Newman D. 2006. The lines that continue to separate us: Borders in our 'borderless' world[J]. Progress in Human Geography, 30(2): 143-161.

Paasi A. 2002. Bounded spaces in the mobile world: Deconstructing 'regional identity'[J]. Tijdschrift voor Economische en Sociale Geografie, 93(2): 137-148.

Prokkola E K. 2011. Cross-border regionalization, the INTERREG III A initiative, and local cooperation at the FinnishSwedish border $[\mathrm{J}]$. Environment and Planning A, 43(5): 1190-1208.

Ravisco M. 2010. Reframing Europe and the global: Conceptualizing the border in cultural encounters[J]. Environment and Planning D: Society and Space, 28(6): 1015-1030.

Scuzzarello S, Kinnvall C. 2013. Rebordering France and Denmark narratives and practices of border-construction in two European countries[J]. Mobilities, 8(1): 90-106.

Shen J F. 2004. Cross- border urban governance in Hong Kong: The role of state in a globalizing city-region[J]. The Professional Geographer, 56(4): 530-543.

Sturgeon J C. 2013. Cross-border rubber cultivation between China and Laos: Regionalization by Akha and Tai rubber farmers[J]. Singapore Journal of Tropical Geography, 34 (1): $70-85$

Turner S. 2013. Under the state's gaze: Upland trading-scapes on the Sino- Vietnamese border[J]. Singapore Journal of Tropical Geography, 34(1): 9-24.

Van Houtum H, Van Naerssen T. 2002. Bordering, ordering and othering $[\mathrm{J}]$. Tijdschrift voor Economische en Sociale Geografie, 93(2): 125-136.

Yeung H W C. 1998. Capital, state and space: Contesting the borderless world[J]. Transactions of the Institute of British Geographers, 23(3): 291-309. 


\title{
Examining festival culture and ethnic identity from the perspective of cross-border mobility:
}

\section{A case study of Huashan Festival at the Sino-Vietnamese borderland}

\author{
TANG Xueqiong', QIAN Junxi², YANG Xihao ${ }^{3}$ \\ (1. School of Landscape, Southwest Forestry University, Kunming 650224, China; 2. Department of Geography, \\ The University of Hong Kong, Hong Kong SAR 999077, China; 3. Center for Cultural Industry and Cultural \\ Geography, School of Geography, South China Normal University, Guangzhou 510631, China)
}

\begin{abstract}
Border is a political institution that not only separates political entities as nation- states with territorially based sovereignty, but also creates potentials for encounter, contact, and exchange. This point of view is particularly relevant to ethnic groups that lead cross-border living, whose lifeworlds are crosscut by de jure borders that impose belonging to nation-states and territorially based citizenship. Yet, the control of borders exercised by sovereign states is never complete or absolute. In contrast, cross-border ethnic groups are usually able to devise myriad tactics and strategies to facilitate border crossing. To interpret the geopolitical implications of such border crossing practices is thus an important academic enterprise for scholars interested in analyzing borderscapes from mundane and bottom-up perspectives. So far, the extant scholarship has pointed to two major lines of arguments that concern the relationship between border crossing and ethnic identity/sense of national belonging. On the one hand, bottom-up and spontaneous mobilities that transcend the confinement of borders are often read as resistance, or at least transgression, to the geopolitical order defined by legal borders. On the other hand, however, it has been warned that an exclusive emphasis on resistance and transgression runs the risk of idealizing cross- border mobilities, while the latter may re- inscribe and consolidate, rather than destabilize identification to nation-states, especially when the radical differences in social, economic, and political niches give rise to heightened perceptions of partition and thus "non-belonging" to a presumed ethnic identity. In this vein, this article proposes the hypothesis that the possibility of cross-border mobility re-inscribing borders and consolidating sense of belonging to nation-state cannot be ruled out. This article uses a case study of crossborder attendance of Huashan Festival at the Sino- Vietnamese borderland. Overall, the empirical findings suggest that the maintenance of cross-border ethnic ties and identity and the assertion of national belonging to China are two processes that are largely co-existence, even mutually reinforcing. The ways in which Huashan celebrations are organized at the two sides of the border are now radically different. While Huashan in Vietnam adheres more loyally to traditional practices, norms, and taboos, the one at the Chinese side has incorporated staged performances to boost local tourism and refashioned ethnic cultural activities to make them in tune with standards and tastes of "modern", "urban” popular cultures. Consequently, Chinese Miao tend to consolidate a sense of belonging to China due to a sense of being "modernized" and culturally superior.
\end{abstract}

Key words: border; cross-border ethnic groups; festival; national identity; ethnic identity 